\title{
Effects of Regional Trade Agreements on Strategic Agricultural Trade in Africa and Its Implications to Food Security: Evidence from Gravity Model Estimation
}

\author{
Fredu Nega Tegebu*, Edris Hussein Seid \\ The Horn Economic and Social Policy Institute (HESPI), Addis Ababa, Ethiopia \\ Email: *tfredu@yahoo.com, *fredu.nega@hespi.org
}

How to cite this paper: Tegebu, F.N. and Seid, E.H. (2019) Effects of Regional Trade Agreements on Strategic Agricultural Trade in Africa and Its Implications to Food Security: Evidence from Gravity Model Estimation. Theoretical Economics Letters, 9, 531-554.

https://doi.org/10.4236/tel.2019.94037

Received: January 24, 2019

Accepted: March 15, 2019

Published: March 18, 2019

Copyright $\odot 2019$ by author(s) and Scientific Research Publishing Inc. This work is licensed under the Creative Commons Attribution International License (CC BY 4.0).

http://creativecommons.org/licenses/by/4.0/

\begin{abstract}
The problems of African agricultural development have been at the forefront of the debate on Africa's development since the Lagos Plan of Action in 1963. During the 2004 AU meeting in Sirte, Libya and subsequently in the 2006 AU/NEPAD Summit on Food Security in Africa, concrete steps have been taken to work towards Common African Market on 12 selected strategic agricultural products. Eight regional trade agreements which are to form the building blocks of the African Economic Community are engaged in trade liberalization and regional integration process on the selected strategic agricultural products with the ultimate goal being the formation of Common Markets for Agricultural products. However, the recent proliferation of regional trade agreements (RTAs) has intensified the debate on their merits especially the merits of south-south trade agreements. This study contributes to this debate by analysing trade creation and trade diversion effects of African RTAs on trade in nine of the twelve strategic agricultural products. An extended gravity model is estimated. We address econometrically the endogeneity of RTAs using a panel approach. Results indicate that African RTAs have mixed effect on trade creation and trade diversion. Net trade creation is positive in three of the eight RTA and it is negative in two. Although a lot remains to be done, RTAs in Africa are an attractive means to speed up the move towards common market for agricultural products in the continent. This will have positive implication for food security and sustainable agricultural development in the continent.
\end{abstract}

\section{Keywords}

Regional Trade Agreements, Food Security, Gravity Model, Africa 


\section{Introduction}

Food security is recognised as being one of the major development challenges facing the African continent. According to [1], the prevalence of undernourishment in Africa was 20.3 and for SSA, it was 23.8 percent, the highest proportion of all developing regions. Africa is not achieving its potential in food trade, increasing the risk of widespread hunger and malnutrition. Trade in agricultural products amongst the African countries remains at a relatively low level. Imports of agricultural products to the continent have been rising faster than exports since the 1970s and Africa as a whole has been a net agricultural importing region since 1980 [2]. Furthermore, it is increasingly being recognised that African food and agricultural markets are extremely fragmented along sub-region, national and even sub-national levels, resulting in segmented markets of sub-optimal size which hinder the profitability of sizeable private investment in the different stages of the commodity chain. These segmented gaps between regional/national production and regional demand are increasingly being filled by imports of non-African origin [in some cases through the use of unfair trade practices], even in case where tradable surpluses exists [2].

These problems and how to overcome them have been at the forefront of the debate on Africa's development since the Lagos Plan of Action in 1963 and the Abuja Treaty of 1991. One way to enhance food security in Africa is to facilitate trade within the continent. Regional integration is a strategy that has been recommended to, and embraced by African countries as the key to improved trade performance and economic development. The current process of regional integration on the continent dates back to the Lagos Plan of Action of 1980. It is based on eight Regional Economic Communities (RECs) which are to form the building blocks of the African Economic Community as set out in the June 1991 Treaty Establishing the African Economic Community (called Abuja Treaty). Each of these RECs is already engaged in a trade liberalization and regional integration process, with the ultimate goal being the formation of a common market and an African Monetary Union. However, the slow progress at overall integration and the worsening food security situation in the continent led African leaders to single out the agricultural sector for fast track creation of an African Common Market for agricultural products without prejudice to the objectives of the Abuja Treaty [2].

In the $2004 \mathrm{AU}$ meeting in Sirte, Libya and subsequently in the December 2006 AU/NEPAD summit on food security in Africa, it has been decided that to achieve significant economies of vertical integration and scale in African agriculture, emphasis should be placed at the regional/sub-regional level around a limited number of strategic commodities without prejudice to ongoing efforts at sector-wide developments. Thus, for selected strategic commodities, a Common African Market that transcends national and sub-regional borders would offer an appropriate economic space to foster private investments at the level of regional economies. This implies that, for the selected strategic commodities, there 
is need to move market integration beyond the current pace of reform to create a free trade zone at the continental level.

The strategic commodities would be those commodities that:

- Represent an important weight in the African food basket

- Weigh significantly in the trade balance in the region through their contribution to foreign exchange earnings or imported in large quantities to make up the gap Africa's production and demand; and

- Have considerable unexploited production potential in Africa, owing mainly to internal supply-side constraints as well as external impediments such as agricultural subsidies and support measures used by Africa's trading partners.

Accordingly, twelve commodities-beef, poultry, dairy products, legumes, maize and maize products, rice, sorghum, groundnut, oil palm, sugar, cotton and cassava-were selected by the African Union.

However, rigorous analysis on how RTAs in Africa is faring in trade in the selected strategic agricultural products has not yet been made. The objective of this study is to analyse the effects of RTAs in Africa on trade in nine of the twelve selected agricultural products, and its implication to food security and sustainable agricultural development. To assess the effects of RTAs in Africa on trade in agricultural products, our investigation relies on a gravity model and disaggregated data. A panel approach is used to address econometrically the endogeneity of RTAs.

The rest of the paper is divided into four sections. Section two reviews the relevant literature, followed by section three which introduces the gravity model and describes the dataset. Results and discussion are presented in section four and finally section five concludes.

\section{Literature Review}

Due to the rapid spread of regional trade agreements (RTAs) in the global trading system in recent years and slow progress in multilateralism, regionalism has emerged as a powerful alternative to multilateralism. African governments and policy makers are convinced more than any time before that regional integration is the key strategy that will enable them to accelerate the transformation of their fragmented small scale economies, expand their markets, widen the region's economic space, and reap the benefits of economies of scale for production and trade, thereby maximizing the welfare of their nations. They consider it as an important path to broad based development and a continental economic community, in accordance with the Treaty Establishing the African Economic Community (1991) and the Constitutive Act of The African Union (2000).

The formation of regional trade blocks has been an important and welldocumented feature of economic integration in Africa. There are 8 regional trade blocks officially recognized by the African Union [3]. Although African regional economic communities were established mostly to promote economic cooperation, they are increasingly active in non-economic areas as well. Many 
are active in the promotion of peace and security within their regions.

The large number of regional trade blocs in Africa suggests that policy makers on the continent believe that trade blocs present opportunities for promoting regional trade, boosting growth and engendering development. However, the effects of RTAs especially south-south agreements on multilateral trade is debatable. A growing literature addresses the debate based on the welfare effects of RTAs and their likely impacts on the multilateral trading system. Several studies advanced pessimistic conclusions about the impact of RTAs on Africa. A World Bank research project on regionalism concluded that South-South regional blocs are problematic in several respects [4]. According to the World Bank study, apart from doubtful non-economic benefits, South-South RTAs between two or more poor countries is very likely to generate trade diversion, especially when external tariffs are high [4]. Similarly, [5] looked at detailed trade data from Sub-Saharan Africa and concluded that, judged by the variance in their trade patterns from what current comparative advantage would predict, intra-regional trade has potential adverse effects on members and on third countries. He concludes that preferences for African intra-trade do not appear to have the potential to make an important impact on these countries' trade... [and] they may have a negative impact on Africa's industrialization and growth if they divert regional imports from low to higher cost sources. Based on a homogenous goods assumption, the same conclusion is advanced by [6] who argues that any RTA between small developing countries will most likely induce a replacement of cheaper imports from the rest of the world with more expensive intra-RTA products from less efficient suppliers. Arguing from a rather different perspective, [7] states that "the smaller the intra-regional shares in total trade... the more likely the trading blocs would become trade diverting". Given the lower intra-trade shares of South-South RTAs (especially African RTAs) compared to North-North or North-South RTAs, the suggestion is once again that SouthSouth RTAs are potentially more trade diverting than other RTAs. Negative impacts of South-South RTAs were found or predicted not only in Africa but also in Latin America.

An equal amount of dissenting opinions are put forward by other studies. For instance, [8] notes that "economic integration [in Africa] could generate the threshold scales necessary to trigger the much-needed strategic complementarities... within the region". Other scholars used CGE analysis and found that trade creation is prevalent in the case of certain South-South RTAs. For instance [9] [10] found positive net effects of regional integration initiatives in Southern Africa, while [11] advances similar conclusions about MERCOSUR. [12] found that African trade blocs did have a positive impact on intraregional trade.

A wide range of techniques have been used to investigate the impact of free trade agreements on the flow of trade, the dominant being the gravity model. The gravity equation is typically used to explain cross-section variation in country pairs' trade flows in terms of the countries' pairs' trade flows in terms of the countries' incomes, bilateral distance, and dummy variables for common lan- 
guages, for common land borders, and for presence or absence of an FTA [13]. The impact of RTAs on trade flows is captured through the use of dummy variables. Early findings on the effects of FTAs and trading blocs on bilateral trade flows were mixed. Recent developments in the empirical literature that deal effectively with two way causality show that trading blocs and free trade agreements have large direct effects on aggregate bilateral trade between member countries relative to non-member countries. [13] have shown that estimation of effects of EIAs suffers from endogeneity bias due to self-selection of country-pairs' government into agreements and further indicate that after accounting for such bias using panel techniques-EIAs had much larger effects on trade flows than revealed in the earler gravity equation literature. The authors indicate that on average a FTA induces approximately a $100 \%$ increase in bilateral trade between members relative to non-member countries within ten years from their inception. Similarly, using panel data sets and controlling for endogeneity, [14] found the first evidence of the differential partial effects of various types of EIAs on intensive and extensive margins of trade with deeper integration agreements having larger impacts on aggregate trade flows. In the same way, [15] finds that larger FTA gains are associated with larger number of FTA partners and larger increase in volumes of trade caused by FTAs.

The paper contributes to the existing debate on south-south trade agreements in two ways. First, it treats problem of endogeneity of trade liberalization measures by taking into account the most recent developments in gravity literature. Second, it assessed all the major RTA in Africa which have not been dealt in detail in previous researches.

\subsection{Regional Integration and Food Security}

The links between regional trade and food security are complex and multiple. Overall, trade is regarded as stimulant of long-term growth by serving as an important channel for diffusion of technology [16] which in turn contributes to poverty reduction and food security. The focus here is explicitly on trade in agri-food commodities and its impact on food security.

Agricultural trade can promote food security in two ways. First, agricultural trade promotes economic growth which in turn improves access to food by improving income. Growth in agriculture contributes more to poverty reduction in developing countries than similar growth in other sectors [17]. This is due to the fact that most households in developing countries depend on agriculture for their living. Moreover, growth in agriculture enhances growth in the rest of the economy as agriculture is the main source of raw materials for the manufacturing sector. Second, agricultural trade increases food availability which in turn reduces food prices and food supply variability leading to increasing food security [18].

Governments can adapt food self-sufficiency, which excludes imports of food items as a source of food supply, or self-reliance which argues that availability of food is most important either produced domestically or sourced by means of in- 
ternational trade. In the light of this paper, it is assumed governments adopt a self-reliance strategy to achieve food security, as this is superior to self-sufficiency in two ways. First, self-sufficiency fails to acknowledge potential gains of trade that are created by international differences in endowment of production factors and technology. Second, a crucial element of food security is a person's access to food, not the extent to which food commodities are produced in a country or region.

Studies on regional trade agreements mainly deal with trade in manufacturing good. Rigorous analysis of effects of RTAs on agricultural trade are scanty. Most studies that focus on effects of RTAs on agricultural trade use descriptive statistical methods, which may not be robust to identify trade effects of RTAs. Econometric techniques have seldom been used to study the effect of RTAs on trade in agricultural products. [19] used extended gravity model on six agrifood products for the North American Free Trade Agreement (NAFTA). While their study does not generate specific information regarding the extent of trade creation and trade diversion for the six commodities attributable to NAFTA, the results do suggest the presence of significant trade creation and diversion effects. Similarly, [20] used an extended gravity model to estimate the magnitude of trade creating and trade diversion across 9 individual agricultural commodities and for 8 RTAs. Results suggest that a majority of regional trade agreements are effective avenues to promote multilateral free trade. Furthermore, with only a few commodity specific exceptions, the authors find that regional trade agreements have increased trade with non-members even as the members have increased trade among themselves to a great extent. Nonetheless, it is important to note that the above empirical evidences did not control for endogeneity of the trade policy variables and hence obtained coefficients might be biased.

Recent studies that deal with issues of endogeneity of trading agreements highlight the importance of trading agreements on agricultural production. By using panel techniques and first differences to deal with endogeneity problems that are inherent to trade policy variables, [21] found that trade preferences granted to Morocco by the EU have a positive and significant effect on Moroccan monthly exports of Fruits and Vegetables. Similarly, [22] explain the importance of trade openness on Total Factor Productivity (TFP) growth in Tunisia indicating the fact that enhanced agricultural trade agreements are beneficial to the agricultural sector as a whole.

The above empirical evidences either do not talk about RTAs in Africa or consider all RTA in Africa as one. Empirical evidences on effect of each RTA in Africa on trade in agricultural products are scanty. This paper fills the evidence gap on effect of South-South RTAs on agricultural products by analysing effects of RTAs in Africa on trade in selected strategic agricultural products.

\subsection{Regional Integration in Africa}

Even though Africa is the least integrated continent, regional integration dates back in the early twentieth century. In 1910 the South African Customs Union 
was formed among Botswana, Lesotho, South Africa and Swaziland. The East African customs union followed suit in 1917 between Kenya and Uganda; and later in 1927 Tanganyika joined the union. Since then large number of economic communities has been formed. At present the African continent has around 14 overlapping regional economic communities [23]. Every country in the continent is at least a member of one REC. Of all the African countries, 25 countries belong to two RECs, 17 are member of three RECs, 6 are members of four RECs. Out of the 14 regional economic communities, 8 are recognized by the African Union Commission (AUC) as building blocks of the African Economic Community which at regional level will start up a process of coordination and harmonization of tariff and non-tariff measures in order to create a continental customs union and eventually an economic and monetary union. Table 1 below lists member countries, year of establishment and status of each of these eight RECs.

Despite the fact that there exist many regional economic communities with overlapping membership in the continent and interests and political commitment of African leaders and policy makers towards regional integration, intra-regional trade in goods and services lags behind other developing regions of

Table 1. African free trade areas and customs union.

\begin{tabular}{|c|c|c|c|}
\hline $\begin{array}{l}\text { Regional Economic } \\
\text { Communities (RECs) }\end{array}$ & Member States & Status & $\begin{array}{c}\text { Year of } \\
\text { Establishment }\end{array}$ \\
\hline $\begin{array}{l}\text { Arab Maghreb Union } \\
\text { (AMU) }\end{array}$ & Algeria, Libya, Mauritania, Morocco, Tunisia & $\begin{array}{l}\text { In progress to eliminate tariffs } \\
\text { \& non-tariff barriers. } \\
\text { Not yet set date for FTA }\end{array}$ & 17 Feb 1989 \\
\hline $\begin{array}{l}\text { Community of } \\
\text { Sahel-Saharan States } \\
\text { (CEN-SAD) }\end{array}$ & $\begin{array}{l}\text { Benin, Burkina Faso, Chad, Cote d'Ivoire, Djibouti, } \\
\text { Egypt, Eritrea, Gambia, Ghana, Guinea-Bissau, } \\
\text { Kenya, Liberia, Libya, Mali, Morocco, Nigeria, Niger, } \\
\text { Senegal, Sierra Leone, Somalia, Sudan, Togo, Tunisia }\end{array}$ & $\begin{array}{l}\text { At the stage of coordinating } \\
\text { and harmonizing activities } \\
\text { among member states }\end{array}$ & 4 February 1998 \\
\hline $\begin{array}{l}\text { Common Market for } \\
\text { Eastern and Southern } \\
\text { Africa (COMESA) }\end{array}$ & $\begin{array}{c}\text { Burundi, Comoros, D.R. Congo, Djibouti, Egypt, } \\
\text { Eritrea, Ethiopia, Kenya, Libya, Seychelles, } \\
\text { Madagascar, Malawi, Mauritius, Rwanda, } \\
\text { Sudan, Swaziland, Uganda, Zambia, Zimbabwe }\end{array}$ & $\begin{array}{l}\text { Custom Union though there are } \\
\text { member states who has not yet } \\
\text { signed even the FRT protocol }\end{array}$ & 8 December 1994 \\
\hline $\begin{array}{l}\text { East African Community } \\
\text { (EAC) }\end{array}$ & Burundi, Kenya, Rwanda, Tanzania, Uganda & Customs Union & 7July 2000 \\
\hline $\begin{array}{l}\text { Economic Community } \\
\text { of Central African States } \\
\text { (ECCAS) }\end{array}$ & $\begin{array}{l}\text { Angola, Burundi, Cameroon, Central African Republic, } \\
\text { Congo, Rep., D.R. Congo, Chad, Gabon, } \\
\text { Equatorial Guinea, Sao Tome and Principe, Rwanda }\end{array}$ & Free Trade Area & 1 July 2007 \\
\hline $\begin{array}{l}\text { Economic Community } \\
\text { of West African States } \\
\text { (ECOWAS) }\end{array}$ & $\begin{array}{l}\text { Benin, Burkina Faso, Cape Verde, Cote d'Ivoire, } \\
\text { Gambia, Ghana, Guinea, Guinea-Bissau, } \\
\text { Liberia, Mali, Niger, Nigeria, Senegal, Sierra Leone, Togo }\end{array}$ & $\begin{array}{l}\text { Free Trade Area and it was } \\
\text { envisioned to create the } \\
\text { Customs Union by } 2015\end{array}$ & 28May 1975 \\
\hline $\begin{array}{l}\text { Inter-Governmental } \\
\text { Authority on Development } \\
\text { (IGAD) }\end{array}$ & $\begin{array}{l}\text { Djibouti, Eritrea, Ethiopia, Kenya, } \\
\text { Somalia, South Sudan, Sudan, Uganda }\end{array}$ & $\begin{array}{l}\text { In progress to eliminate tariff } \\
\text { and non-tariff barriers. } \\
\text { Not yet set date for FTA }\end{array}$ & 25 November 1996 \\
\hline
\end{tabular}


Asia and Latin America [23]. The low level of intra-regional trade in merchandise goods is observed in agricultural commodities in which most African countries heavily rely on for foreign exchange earnings and employment. These African RECs, as shown below in Table 2, traded less among themselves compared to other RECs (such as ASEAN, NAFTA and EU). In 2012, COMESA and SADC recorded the highest intra-regional trade in agricultural commodities with 20.7 and 23.3 percent respectively. While the intra-regional trade in EU and NAFTA was well above 70 and 40 percent respectively.

\section{Empirical Analysis}

\subsection{The Gravity Model}

The gravity model has been used widely as a baseline model for estimating the impact of economic integration upon the volume and direction of international trade flows. It has performed remarkably well as an empirical framework for measuring the impact of regional integration arrangements [24] [25].

Typically, in the case of gravity model of trade, bilateral trade flows are dependent upon the size of the two economies and the distance between them:

$$
X_{i j}^{t}=f\left(Y_{i}^{t}, Y_{j}^{t}, D_{i j}\right)
$$

where $X_{i j}^{t}$ are exports from country $i$ to country $j$ at time $t, Y_{i}^{t}$ and $Y_{j}^{t}$ are the GDPs at time $t$ of countries $i$ and $j$ respectively. D is the distance between the capital cities of the two countries.

The rationale behind the gravity model is that trade is associated with economic size, measured as GDP, and is inhibited by distance (which increases transportation costs, as well as other transaction costs). Specifically, a high level of income in the exporting country indicates a high level of production, which increases the availability of products from export while a high level of income in

Table 2. Intra-regional trade (exports) among selected RECs in agricultural goods.

\begin{tabular}{ccccccccccccc}
\hline & 2001 & 2002 & 2003 & 2004 & 2005 & 2006 & 2007 & 2008 & 2009 & 2010 & 2011 & 2012 \\
\hline CEN-SAD & 13.1 & 12.0 & 11.2 & 10.5 & 11.3 & 11.7 & 12.1 & 13.5 & 13.8 & 14.7 & 15.1 & 15.5 \\
COMESA & 12.2 & 13.2 & 10.8 & 12.3 & 12.5 & 16.1 & 16.9 & 17.3 & 16.7 & 20.0 & 18.5 & 20.7 \\
EAC & 6.2 & 5.9 & 7.6 & 8.3 & 8.0 & 8.5 & 11.0 & 10.7 & 11.7 & 12.9 & 14.2 & 15.9 \\
ECCAS & 8.2 & 8.4 & 8.9 & 8.2 & 7.7 & 11.8 & 11.3 & 11.1 & 9.6 & 10.2 & 10.9 & 12.9 \\
ECOWAS & 11.1 & 9.9 & 10.0 & 10.8 & 10.4 & 10.7 & 11.1 & 12.5 & 12.2 & 11.3 & 12.2 & 11.8 \\
IGAD & 8.7 & 8.7 & 8.3 & 7.8 & 8.6 & 10.3 & 10.5 & 11.9 & 13.0 & 15.1 & 14.1 & 15.0 \\
SADC & 19.2 & 23.3 & 22.9 & 23.5 & 20.6 & 21.3 & 21.6 & 23.4 & 25.0 & 24.0 & 24.0 & 23.6 \\
UMA & 6.9 & 8.6 & 7.8 & 6.1 & 7.4 & 7.7 & 7.8 & 7.9 & 7.7 & 8.1 & 13.3 & 12.2 \\
ASEAN & 20.0 & 19.8 & 19.7 & 19.5 & 19.5 & 19.2 & 19.6 & 18.9 & 19.7 & 21.6 & 21.7 & 22.5 \\
EU & 75.2 & 75.5 & 76.4 & 77.2 & 77.3 & 76.9 & 77.3 & 77.1 & 77.7 & 75.8 & 74.8 & 73.7 \\
NAFTA & 42.8 & 44.8 & 43.9 & 45.5 & 47.0 & 47.3 & 43.6 & 40.5 & 41.6 & 40.8 & 40.9 & 40.5 \\
\hline
\end{tabular}

Source: UNCTAD stat. 
the importing country suggests higher demand and therefore, higher imports. Therefore both $Y_{i}^{t}$ and $Y_{j}^{t}$ should be positively correlated with the level of bilateral exports. Since distance increases transport costs, its coefficient is expected to be negative.

For estimation purposes, the basic gravity model is most often used in its log-linear form:

$$
\ln \left(X_{i j}^{t}\right)=\beta_{0}+\beta_{1} \ln \left(Y_{i}^{t}\right)+\beta_{2} \log \left(Y_{j}^{t}\right)+\beta_{3} \ln \left(D_{i j}\right)+\varepsilon_{i j t}
$$

where $\varepsilon_{i j t}$ is the log normally-distributed error term.

We are interested in a model that captures the trade flow effects of regional trade agreements. Researchers typically experiment by including proxies for trade costs such as the distance between partners, and indicators for common language and contiguity (when countries share land borders). For example, two countries that share a common border or speak a common language may trade more with each other based on relative proximity and cultural similarity. Or, countries with access to sea port may have a comparative advantage in trade relative to neighbours who are landlocked. Controlling for these factors gives us more confidence that our regional block dummies are picking up structural increases in trade following the signing of an RTA.

Thus, the most commonly used version of the expanded gravity model assessing the impact of RTAs is the following:

$$
\begin{aligned}
& \ln \left(X_{i j}^{t}\right)=\beta_{0}+\beta_{1} \ln \left(Y_{i}^{t}\right)+\beta_{2} \ln \left(Y_{j}^{t}\right)+\beta_{3} \ln \left(\frac{Y_{i}^{t}}{N_{i}^{t}}\right)+\beta_{4} \ln \left(\frac{Y_{j}^{t}}{N_{j}^{t}}\right) \\
& +\beta_{5} \ln D_{i j}+\beta_{6} \ln \text { linder }+\beta_{7} \text { cont }_{i j}+\beta_{8} \text { commlang }_{i j} \\
& +\beta_{9} \text { landlck }_{i}+\beta_{10} \text { landlck }_{j}+\sum_{h=1}^{8} \alpha_{h} \text { TradeC }_{i j h}^{t} \\
& +\sum_{l=1}^{8} \gamma_{h} \operatorname{TradeD}_{i j l}^{t}+\text { TimeDummies }+\varepsilon_{i j}^{t}
\end{aligned}
$$

where cont $_{i j}$, commlang $_{i j}$ and landlck $_{i j}$ are dummy variables equal to one if exporter (i) and importer ( $\mathrm{j}$ ) share a common land border, speak a common language or are landlocked countries and zero otherwise, and the variable linder calculated as per capita difference between two trading partners shows differences in tastes.

The dummy variables $\operatorname{Trade}_{i j h}^{t}$ and $\operatorname{Trade}_{i j l}^{t}$ are designed to capture trade creation or trade diversion effects respectively in agricultural products trade for eight RTAs $(h=1,2, \cdots, 8)$. The dummy variable $\operatorname{Trade}_{i j h}^{t}$ equals one if countries $i$ and $j$ belong to a particular RTA and the year $(\mathrm{t})$ is greater than or equal to the year the agreement was signed. The sign and magnitude of the coefficient indicates whether the creation of a particular RTA has stimulated or depressed intra-regional agricultural trade.

The trade diversion dummy variable ( $\left.\operatorname{Trade}_{i j l}^{t}\right)$ is designed to estimate how much of the increase (if any) in trade creation came as a result of trade diversion from non-member sources. Trade diversion is defined in terms of import costs. 
This variable takes the value one when the importer is an RTA member and the exporter a non-member and the year $(t)$ is greater than or equal to the year the agreement was signed, and zero otherwise. Thus, the coefficient will capture the average increase (decrease) in trade diversion from non-member sources after the agreement came into force.

To obtain econometrically sound estimates of the parameters of interest from Equation (3) above, we address the presence of endogeneity of free trade agreements and unobservable multilateral resistance terms.

Following the developments in the empirical gravity literature, we use time-varying directional (source and destination), country-specific dummies to control for the multilateral resistances. To account for RTA endogeneity, we use the panel data estimation techniques described in [26] and first applied to a similar setting by [13] who employ aggregate data to show that direct FTA effects on bilateral trade flows can be consistently isolated in a theoretically-founded gravity model by using country-pair fixed effects. Similar methodology has been used by few other studies (see for e.g. [14] [15]).

Taking the above considerations into account, we estimate the following econometric specification for each class of commodities in our sample:

$$
\ln X_{i j}^{t}=\exp \left[\beta_{0}+\eta_{i}^{t}+\theta_{j}^{t}+\gamma_{i j}+\sum_{h=1}^{8} R T A C_{i j h}^{t}+\sum_{h=1}^{8} R T A C_{i j l}^{t}+\epsilon_{i j}^{t}\right]
$$

where $\ln X_{i j}^{t}$ is bilateral trade (in logarithmic form) between partners $i$ and $j$ at time t. $R T A C_{i j h}^{t}$ and $R T A C_{i j l}^{t}$ are dummy variables designed to capture trade creation or trade diversion effects respectively for each of the eight RTAs. The dummy variable $R T A C_{i j h}^{t}$ equals 1 if countries $i$ and $j$ belong to a particular RTA and the year $(t)$ is greater than or equal to the year the agreement was signed. The trade diversion dummy variable $R T A C_{i j l}^{t}$ is designed to estimate how much of the increase (if any) in trade creation came as a result of trade diversion from non-member sources. $\eta_{i}^{t}$ denotes the time-varying source-country dummies, which control for the (log of) outward multilateral resistances and total shipments. $\theta_{j}^{t}$ encompasses the time varying destination country dummy variables that account for the (log of) inward multilateral resistances and total expenditure. $\gamma_{i j}$ captures the country-pair fixed effects used to address FTA endogeneity.

\subsection{Data}

Data was obtained from different sources. Table 3 presents the data source and description of variables used.

\section{Estimated Results and Discussion}

Regression results from the 10 regression scenarios (separate regression for each of the 9 selected agricultural products and one regression for all the selected agricultural products) are displayed in Tables 4-6. The regression scenarios are labelled 1 through 10 accordingly. The standard or traditional gravity estimates are reported on Table 4 . Table 5 and Table 6 present the trade creation and trade diversion coefficients respectively. 
Table 3. Variable description and data source.

\begin{tabular}{|c|c|c|}
\hline Variable & Description & Data Sources \\
\hline GDP & Nominal GDP as measure of economic mass (taken in log form) & World Development Indicators (WDI) \\
\hline GDP per capita & & World Development Indicators (WDI) \\
\hline Linder & $\begin{array}{l}\text { It is the absolute value of the difference in GDP per Capita } \\
\text { income included to measure income difference }\end{array}$ & $\begin{array}{l}\text { Authors computation } \\
\text { using the GDP per capita variable }\end{array}$ \\
\hline Bilateral Trade data & $\begin{array}{l}\text { Panel bilateral trade data for the } 9 \text { strategic agricultural } \\
\text { commodities for the period } 1998 \text { to } 2010 \text { for all African } \\
\text { countries and selected Industrial and Emerging Economies }\end{array}$ & CEPII Gravity Database \\
\hline Area & Area in square $\mathrm{km}$ & CEPII GeoDist Database \\
\hline Landlocked & 1 if landlocked, 0 otherwise & CEPII GeoDist Database \\
\hline Bilateral Distance & $\begin{array}{l}\text { Distance between the trading partners as developed by [27] } \\
\text { is computed based on latitude and longitude of the capital cities. }\end{array}$ & CEPII GeoDist Database \\
\hline Contiguity & 1 if share common border, $=0$ otherwise & CEPII GeoDist Database \\
\hline Language & 1 if have common official or primary language & CEPII GeoDist Database \\
\hline Colony & 1 if had common colonizer, $=0$ otherwise & CEPII GeoDist Database \\
\hline Population & Population size of the trading partners taken in log & World Development Indicators (WDI) \\
\hline TradeC $C_{i j h}^{t}$ & $\begin{array}{l}1 \text { if countries i \& j belong to a particular RTA and the year }(\mathrm{t}) \text { is greater } \\
\text { than or equal to the year the agreement was signed, } 0 \text { otherwise }\end{array}$ & Authors' compilation from different sources \\
\hline TradeD $D_{i j l}^{t}$ & $\begin{array}{l}1 \text { if the importer is an RTA member \& the exporter a non-member } \\
\text { and the year }(t) \text { is greater than or equal to the year the agreement } \\
\text { was signed, } 0 \text { otherwise }\end{array}$ & Authors' compilation from different sources \\
\hline
\end{tabular}

Table 4. Gravity model regression results for standard gravity variables.

\begin{tabular}{|c|c|c|c|c|c|c|c|c|c|c|}
\hline & (1) & (2) & (3) & (4) & (5) & (6) & (7) & (8) & (9) & (10) \\
\hline & sorghum & beef & poultry & dairy & oilpalm & groundnut & legumes & rice & sugar & total \\
\hline Area_partner & $\begin{array}{l}-0.316^{*} \\
(-2.10)\end{array}$ & $\begin{array}{c}-0.394^{* * *} \\
(-4.57)\end{array}$ & $\begin{array}{c}-0.330^{* * *} \\
(-3.94)\end{array}$ & $\begin{array}{c}0.191^{* * *} \\
(3.68)\end{array}$ & $\begin{array}{c}0.301^{* * *} \\
(4.15)\end{array}$ & $\begin{array}{c}-0.246^{* *} \\
(-2.67)\end{array}$ & $\begin{array}{c}-0.535^{* * *} \\
(-9.20)\end{array}$ & $\begin{array}{c}-0.975^{* * *} \\
(-8.38)\end{array}$ & $\begin{array}{c}-0.817^{* * *} \\
(-15.07)\end{array}$ & $\begin{array}{c}-0.567^{* * *} \\
(-14.25)\end{array}$ \\
\hline Area_reporter & $\begin{array}{c}0.940^{* * *} \\
(6.32)\end{array}$ & $\begin{array}{l}-0.184^{*} \\
(-2.10)\end{array}$ & $\begin{array}{c}-1.243^{* * *} \\
(-14.30)\end{array}$ & $\begin{array}{c}-1.097^{* * *} \\
(-21.39)\end{array}$ & $\begin{array}{c}-0.331^{* * *} \\
(-4.66)\end{array}$ & $\begin{array}{l}0.221^{*} \\
(2.29)\end{array}$ & $\begin{array}{c}-0.0842 \\
(-1.47)\end{array}$ & $\begin{array}{c}-3.175^{* * *} \\
(-24.88)\end{array}$ & $\begin{array}{c}-1.963^{* * *} \\
(-30.80)\end{array}$ & $\begin{array}{c}-1.727^{* * *} \\
(-45.87)\end{array}$ \\
\hline Distance & $\begin{array}{c}-1.381^{\star * *} \\
(-4.81)\end{array}$ & $\begin{array}{c}-2.583^{\star * *} \\
(-11.95)\end{array}$ & $\begin{array}{c}-1.040^{\star * *} \\
(-5.87)\end{array}$ & $\begin{array}{c}-1.785^{\star * *} \\
(-13.04)\end{array}$ & $\begin{array}{c}-2.225^{\star * *} \\
(-13.02)\end{array}$ & $\begin{array}{c}-1.349^{* * *} \\
(-7.38)\end{array}$ & $\begin{array}{c}-1.506^{\star * *} \\
(-12.47)\end{array}$ & $\begin{array}{c}-2.851^{\star * *} \\
(-9.76)\end{array}$ & $\begin{array}{c}-1.324^{\star * *} \\
(-7.72)\end{array}$ & $\begin{array}{c}-1.654^{\star * *} \\
(-13.14)\end{array}$ \\
\hline GDP_partner & $\begin{array}{c}1.667^{* * *} \\
(8.90)\end{array}$ & $\begin{array}{c}0.789^{* * *} \\
(8.10)\end{array}$ & $\begin{array}{c}0.659^{* * *} \\
(6.62)\end{array}$ & $\begin{array}{c}0.162^{* *} \\
(2.72)\end{array}$ & $\begin{array}{l}0.0980 \\
(1.15)\end{array}$ & $\begin{array}{c}1.034^{* * *} \\
(9.84)\end{array}$ & $\begin{array}{c}1.258^{* * *} \\
(19.55)\end{array}$ & $\begin{array}{c}2.132^{* * *} \\
(16.44)\end{array}$ & $\begin{array}{c}2.168^{* * *} \\
(34.60)\end{array}$ & $\begin{array}{c}1.645^{* * *} \\
(46.36)\end{array}$ \\
\hline GDP_reporter & $\begin{array}{c}1.395^{\star * *} \\
(7.39)\end{array}$ & $\begin{array}{c}2.074^{* \star \star} \\
(25.53)\end{array}$ & $\begin{array}{c}2.682^{\star * *} \\
(19.04)\end{array}$ & $\begin{array}{c}2.402^{* \star \star} \\
(34.78)\end{array}$ & $\begin{array}{c}0.835^{* * *} \\
(9.80)\end{array}$ & $\begin{array}{c}0.564^{* * *} \\
(5.01)\end{array}$ & $\begin{array}{c}1.353^{* * *} \\
(19.29)\end{array}$ & $\begin{array}{c}6.938^{* * *} \\
(34.51)\end{array}$ & $\begin{array}{c}4.302^{\star * *} \\
(49.96)\end{array}$ & $\begin{array}{c}3.253^{* * *} \\
(79.97)\end{array}$ \\
\hline GDPPC_partner & $\begin{array}{l}-0.384 \\
(-1.86)\end{array}$ & $\begin{array}{c}0.414^{* * *} \\
(3.78)\end{array}$ & $\begin{array}{c}-0.298^{\star *} \\
(-2.81)\end{array}$ & $\begin{array}{c}0.204^{\star *} \\
(3.21)\end{array}$ & $\begin{array}{c}0.392^{* \star *} \\
(4.00)\end{array}$ & $\begin{array}{c}0.000588 \\
(0.00)\end{array}$ & $\begin{array}{c}-0.902^{\star * \star} \\
(-12.54)\end{array}$ & $\begin{array}{c}-2.170^{* \star \star} \\
(-16.17)\end{array}$ & $\begin{array}{c}-1.828^{\star * \star} \\
(-26.78)\end{array}$ & $\begin{array}{c}-1.287^{* * *} \\
(-33.83)\end{array}$ \\
\hline GDPPC_reporter & $\begin{array}{c}-1.692^{* * *} \\
(-7.38)\end{array}$ & $\begin{array}{c}-0.607^{* * *} \\
(-6.58)\end{array}$ & $\begin{array}{c}-2.760^{* * *} \\
(-15.48)\end{array}$ & $\begin{array}{c}-2.149^{* * *} \\
(-25.66)\end{array}$ & $\begin{array}{c}-0.689^{* * *} \\
(-7.04)\end{array}$ & $\begin{array}{c}-1.011^{* * *} \\
(-8.86)\end{array}$ & $\begin{array}{c}-1.229^{* * *} \\
(-16.43)\end{array}$ & $\begin{array}{c}-7.666^{* * *} \\
(-37.14)\end{array}$ & $\begin{array}{c}-4.189^{* * *} \\
(-45.46)\end{array}$ & $\begin{array}{c}-3.334^{* * *} \\
(-76.74)\end{array}$ \\
\hline Linder & $\begin{array}{c}0.482^{\star * \star} \\
(8.32)\end{array}$ & $\begin{array}{c}-0.0215^{*} \\
(-2.23)\end{array}$ & $\begin{array}{c}0.175^{\star * \star} \\
(4.26)\end{array}$ & $\begin{array}{c}0.0886^{* * *} \\
(6.42)\end{array}$ & $\begin{array}{c}-0.113^{* * *} \\
(-7.29)\end{array}$ & $\begin{array}{c}0.320^{\star * *} \\
(11.94)\end{array}$ & $\begin{array}{c}0.301^{\star * *} \\
(21.69)\end{array}$ & $\begin{array}{c}-0.0275^{\star * *} \\
(-5.04)\end{array}$ & $\begin{array}{r}* 0.0236^{\star *} \\
(-3.15)\end{array}$ & $\begin{array}{c}0.00208 \\
(0.66)\end{array}$ \\
\hline Landlocked_partner & $\begin{array}{c}3.049^{* * *} \\
(8.32)\end{array}$ & $\begin{array}{c}-1.687^{* * *} \\
(-5.14)\end{array}$ & $\begin{array}{c}-1.182^{* * *} \\
(-4.86)\end{array}$ & $\begin{array}{c}-0.763^{* * *} \\
(-4.54)\end{array}$ & $\begin{array}{l}0.170 \\
(0.77)\end{array}$ & $\begin{array}{l}-0.192 \\
(-0.67)\end{array}$ & $\begin{array}{c}-0.539^{* *} \\
(-3.14)\end{array}$ & $\begin{array}{c}-1.027^{* *} \\
(-2.65)\end{array}$ & $\begin{array}{c}-2.153^{* * *} \\
(-8.75)\end{array}$ & $\begin{array}{c}-0.545^{* *} \\
(-3.00)\end{array}$ \\
\hline
\end{tabular}




\section{Continued}

\begin{tabular}{|c|c|c|c|c|c|c|c|c|c|c|}
\hline Landlocked_reporter & $\begin{array}{c}-1.973^{* * *} \\
(-3.99)\end{array}$ & $\begin{array}{c}2.744^{* * *} \\
(10.32)\end{array}$ & $\begin{array}{c}-1.454^{* * *} \\
(-5.32)\end{array}$ & $\begin{array}{c}-1.984^{* * *} \\
(-11.53)\end{array}$ & $\begin{array}{c}-2.914^{* * *} \\
(-11.37)\end{array}$ & $\begin{array}{c}-2.153^{\star * *} \\
(-7.04)\end{array}$ & $\begin{array}{l}0.0298 \\
(0.18)\end{array}$ & $\begin{array}{l}-0.529 \\
(-1.26)\end{array}$ & $\begin{array}{c}1.302^{\star * *} \\
(6.19)\end{array}$ & $\begin{array}{l}-0.183 \\
(-1.18)\end{array}$ \\
\hline Contiguity & $\begin{array}{c}3.447^{* * *} \\
(4.50)\end{array}$ & $\begin{array}{c}2.570^{* * *} \\
(5.77)\end{array}$ & $\begin{array}{c}2.535^{* * *} \\
(5.71)\end{array}$ & $\begin{array}{c}2.308^{* * *} \\
(7.06)\end{array}$ & $\begin{array}{l}0.823 \\
(1.84)\end{array}$ & $\begin{array}{c}2.980^{* * *} \\
(6.83)\end{array}$ & $\begin{array}{c}1.744^{* * *} \\
(5.00)\end{array}$ & $\begin{array}{l}2.308^{* *} \\
(2.94)\end{array}$ & $\begin{array}{c}1.786^{* * *} \\
(3.67)\end{array}$ & $\begin{array}{c}2.735^{* * *} \\
(8.36)\end{array}$ \\
\hline Common language_off & $\begin{array}{l}0.894^{*} \\
(2.31)\end{array}$ & $\begin{array}{c}0.717^{* *} \\
(3.08)\end{array}$ & $\begin{array}{l}0.190 \\
(0.87)\end{array}$ & $\begin{array}{c}-0.0508 \\
(-0.32)\end{array}$ & $\begin{array}{c}0.545^{* *} \\
(2.71)\end{array}$ & $\begin{array}{l}0.411 \\
(1.65)\end{array}$ & $\begin{array}{l}0.262 \\
(1.73)\end{array}$ & $\begin{array}{l}0.335 \\
(0.96)\end{array}$ & $\begin{array}{c}-0.0229 \\
(-0.11)\end{array}$ & $\begin{array}{l}0.272 \\
(1.73)\end{array}$ \\
\hline Colony & $\begin{array}{l}0.0491 \\
(0.07)\end{array}$ & $\begin{array}{l}1.031^{\star} \\
(2.10)\end{array}$ & $\begin{array}{c}1.993^{* * *} \\
(4.82)\end{array}$ & $\begin{array}{l}0.970^{* *} \\
(2.73)\end{array}$ & $\begin{array}{l}0.486 \\
(1.12)\end{array}$ & $\begin{array}{c}1.733^{* * *} \\
(3.65)\end{array}$ & $\begin{array}{c}1.691^{* * *} \\
(5.10)\end{array}$ & $\begin{array}{l}0.0580 \\
(0.09)\end{array}$ & $\begin{array}{c}1.959^{* * *} \\
(4.42)\end{array}$ & $\begin{array}{c}0.878^{* *} \\
(2.58)\end{array}$ \\
\hline Constant & $\begin{array}{c}-69.68^{* * *} \\
(-17.42)\end{array}$ & $\begin{array}{c}-43.49^{* * *} \\
(-22.16)\end{array}$ & $\begin{array}{c}-33.62^{\star * *} \\
(-15.80)\end{array}$ & $\begin{array}{c}-22.14^{* * *} \\
(-14.89)\end{array}$ & $\begin{array}{l}-1.159 \\
(-0.64)\end{array}$ & $\begin{array}{c}-25.89^{\star * *} \\
(-13.86)\end{array}$ & $\begin{array}{c}-30.91^{\star * *} \\
(-23.71)\end{array}$ & $\begin{array}{c}-71.42^{\star * *} \\
(-26.33)\end{array}$ & $\begin{array}{c}-62.75^{* * *} \\
(-32.44)\end{array}$ & $\begin{array}{c}-38.10^{* * *} \\
(-32.93)\end{array}$ \\
\hline lnalpha_cons & $\begin{array}{c}2.814^{* * *} \\
(32.17)\end{array}$ & $\begin{array}{c}2.525^{\star * *} \\
(48.68)\end{array}$ & $\begin{array}{c}2.399^{* * *} \\
(40.28)\end{array}$ & $\begin{array}{c}2.157^{* * *} \\
(52.24)\end{array}$ & $\begin{array}{c}2.641^{* * *} \\
(52.05)\end{array}$ & $\begin{array}{c}2.629^{* * *} \\
(46.19)\end{array}$ & $\begin{array}{c}2.143^{* * *} \\
(50.89)\end{array}$ & $\begin{array}{c}3.018^{* * *} \\
(62.31)\end{array}$ & $\begin{array}{c}2.712^{\star * *} \\
(79.88)\end{array}$ & $\begin{array}{c}2.220^{* * *} \\
(80.53)\end{array}$ \\
\hline$N$ & 42256 & 42256 & 42256 & 42256 & 42256 & 42256 & 42256 & 42256 & 42256 & 42256 \\
\hline
\end{tabular}

$t$ statistics in parentheses; for brevity time dummy variable are not reported; ${ }^{*} p<0.05,{ }^{* *} p<0.01,{ }^{* * *} p<0.001$.

Table 5. Trade creation for the RECs (at commodity level).

\begin{tabular}{|c|c|c|c|c|c|c|c|c|c|c|}
\hline & $\begin{array}{c}(1) \\
\text { Sorghum }\end{array}$ & $\begin{array}{l}\text { (2) } \\
\text { Sugar }\end{array}$ & $\begin{array}{l}(3) \\
\text { Rice }\end{array}$ & $\begin{array}{c}(4) \\
\text { Poultry }\end{array}$ & $\begin{array}{c}(5) \\
\text { Oil palm }\end{array}$ & $\begin{array}{c}(6) \\
\text { Legumes }\end{array}$ & $\begin{array}{c}(7) \\
\text { Dairy }\end{array}$ & $\begin{array}{c}(8) \\
\text { Beef }\end{array}$ & $\begin{array}{c}\text { (9) } \\
\text { Ground Nut }\end{array}$ & $\begin{array}{l}(10) \\
\text { Total }\end{array}$ \\
\hline \multirow[t]{2}{*}{ AMU } & 0.0457 & 0.543 & 0.323 & $-1.256^{* * *}$ & 0.0796 & 0.481 & 0.493 & 0.125 & -0.285 & 0.216 \\
\hline & $(0.85)$ & $(1.71)$ & (1.13) & $(-5.67)$ & $(0.38)$ & (1.41) & (1.59) & $(0.70)$ & $(-1.06)$ & $(0.53)$ \\
\hline \multirow[t]{2}{*}{ CEN-SAD } & $-1.323^{* * *}$ & $-3.662^{* * *}$ & $-2.417^{\star * \star}$ & -0.211 & -1.121 & $-4.587^{* * *}$ & $-5.242^{\star * *}$ & 0.049 & $-1.927^{\star *}$ & $-3.556^{\star *}$ \\
\hline & $(-4.64)$ & $(-3.67)$ & $(-3.37)$ & $(-0.31)$ & $(-1.75)$ & $(-4.94)$ & $(-5.99)$ & -0.08 & $(-2.83)$ & $(-3.10)$ \\
\hline \multirow[t]{2}{*}{ COMESA } & 0.0878 & 0.455 & -0.0275 & 0.469 & 0.316 & 0.596 & 0.55 & $1.104^{\star \star}$ & 0.442 & $1.168^{*}$ \\
\hline & $(0.58)$ & $(1.25)$ & $(-0.11)$ & $(1.54)$ & (1.17) & $(1.29)$ & $(1.53)$ & (2.59) & (1.34) & $(2.40)$ \\
\hline \multirow[t]{2}{*}{ EAC } & 0.231 & $1.903^{*}$ & $1.802^{*}$ & 0.624 & $1.424^{\star}$ & 0.251 & 0.692 & 1.132 & 0.595 & $2.370^{\star *}$ \\
\hline & $(0.41)$ & (2.18) & $(2.35)$ & $(1.42)$ & $(2.29)$ & $(0.27)$ & $(1.24)$ & $(1.70)$ & (1.08) & $(3.20)$ \\
\hline \multirow[t]{2}{*}{ ECCAS } & 0.0531 & $-1.378^{\star *}$ & -0.0462 & $-1.799^{* * *}$ & -0.0007 & 0.397 & $-0.943^{*}$ & 0.0298 & -0.337 & $-2.549^{\star * *}$ \\
\hline & -0.85 & $(-3.12)$ & $(-0.10)$ & $(-5.03)$ & $(-0.00)$ & $(1.02)$ & $(-2.14)$ & $(0.12)$ & $(-1.06)$ & $(-4.62)$ \\
\hline \multirow[t]{2}{*}{ ECOWAS } & 0.0169 & -0.441 & -0.207 & -0.313 & -0.0235 & 0.127 & -0.533 & -0.0186 & -0.0042 & -0.109 \\
\hline & $(0.31)$ & $(-1.09)$ & $(-0.48)$ & $(-1.07)$ & $(-0.11)$ & $(0.36)$ & $(-1.10)$ & $(-0.08)$ & $(-0.01)$ & $(-0.23)$ \\
\hline \multirow[t]{2}{*}{ IGAD } & $4.536^{* * *}$ & $6.776^{* * *}$ & $4.780^{* * *}$ & -0.113 & $3.971^{* * *}$ & $4.314^{\star * *}$ & $3.457^{\star * *}$ & 0.531 & $1.811^{* *}$ & $6.746^{* * *}$ \\
\hline & (15.13) & $(9.61)$ & $(8.26)$ & $(-0.22)$ & $(8.46)$ & $(5.46)$ & $(4.91)$ & $(0.91)$ & $(3.02)$ & (7.67) \\
\hline \multirow[t]{2}{*}{ SADC } & 0.149 & 0.842 & 0.383 & 0.428 & -0.167 & -0.301 & -0.0706 & -0.0405 & 0.0443 & 0.611 \\
\hline & $(1.00)$ & $(1.47)$ & $(1.27)$ & $(1.66)$ & $(-0.44)$ & $(-0.99)$ & $(-0.20)$ & $(-0.19)$ & $(0.23)$ & $(0.97)$ \\
\hline Country pair FE & Yes & Yes & Yes & Yes & Yes & Yes & Yes & Yes & Yes & Yes \\
\hline Reporter FE & Yes & Yes & Yes & Yes & Yes & Yes & Yes & Yes & Yes & Yes \\
\hline Partner FE & Yes & Yes & Yes & Yes & Yes & Yes & Yes & Yes & Yes & Yes \\
\hline \multirow[t]{2}{*}{ _cons } & $1.255^{\star * *}$ & $4.936^{* * *}$ & $2.490^{\star * *}$ & $1.879^{* * *}$ & $1.121^{*}$ & $4.238^{\star * *}$ & $6.020^{\star * *}$ & -0.219 & $2.191^{* * *}$ & $5.950^{* * *}$ \\
\hline & $(4.80)$ & $(6.21)$ & $(5.30)$ & $(3.86)$ & $(2.15)$ & $(6.47)$ & $(9.62)$ & $(-0.41)$ & $(4.77)$ & $(6.74)$ \\
\hline$N$ & 13924 & 13924 & 13924 & 13924 & 13924 & 13924 & 13924 & 13924 & 13924 & 13924 \\
\hline
\end{tabular}

$t$ statistics in parentheses. ${ }^{*} p<0.05,{ }^{* *} p<0.01,{ }^{* * *} p<0.001$. 
Table 6. Trade Diversion for the RECs (at commodity level).

\begin{tabular}{|c|c|c|c|c|c|c|c|c|c|c|}
\hline & $\begin{array}{c}(1) \\
\text { Sorghum }\end{array}$ & $\begin{array}{l}(2) \\
\text { Sugar }\end{array}$ & $\begin{array}{l}\text { (3) } \\
\text { Rice }\end{array}$ & $\begin{array}{c}(4) \\
\text { Poultry }\end{array}$ & $\begin{array}{c}(5) \\
\text { Oil Palm }\end{array}$ & $\begin{array}{c}(6) \\
\text { Legumes }\end{array}$ & $\begin{array}{c}\text { (7) } \\
\text { Dairy }\end{array}$ & $\begin{array}{l}\text { (8) } \\
\text { Beef }\end{array}$ & $\begin{array}{c}\text { (9) } \\
\text { Ground Nut }\end{array}$ & $\begin{array}{l}(10) \\
\text { Total }\end{array}$ \\
\hline \multirow[t]{2}{*}{ AMU } & 0.102 & -0.418 & 0.0858 & -0.654 & 0.0778 & 0.664 & -0.827 & 0.251 & -0.252 & -0.423 \\
\hline & $(0.81)$ & $(-1.05)$ & $(0.19)$ & $(-1.85)$ & $(0.29)$ & (1.68) & $(-1.92)$ & $(0.95)$ & $(-0.80)$ & $(-0.85)$ \\
\hline \multirow[t]{2}{*}{ CEN-SAD } & $-1.413^{* * *}$ & $-4.726^{* * *}$ & $-2.507^{\star * *}$ & $-1.382^{*}$ & -1.132 & $-4.661^{* * *}$ & $-5.674^{* * *}$ & -0.16 & $-2.069^{\star *}$ & $-5.723^{\star * *}$ \\
\hline & $(-5.10)$ & $(-4.86)$ & $(-3.58)$ & $(-2.15)$ & $(-1.79)$ & $(-5.08)$ & $(-6.68)$ & $(-0.28)$ & $(-3.11)$ & $(-5.11)$ \\
\hline \multirow[t]{2}{*}{ COMESA } & 0.18 & 0.349 & 0.0708 & 0.456 & 0.248 & 0.804 & 0.624 & $1.157^{\star *}$ & 0.548 & $1.086^{\star}$ \\
\hline & $(1.16)$ & $(0.99)$ & $(0.29)$ & $(1.45)$ & $(0.92)$ & (1.77) & $(1.72)$ & $(2.71)$ & $(1.63)$ & $(2.42)$ \\
\hline \multirow[t]{2}{*}{ EAC } & -0.111 & -0.102 & -0.246 & -0.0143 & -0.0989 & -0.461 & -0.455 & -0.0965 & 0.136 & -0.423 \\
\hline & $(-0.91)$ & $(-0.31)$ & $(-0.99)$ & $(-0.08)$ & $(-0.50)$ & $(-1.93)$ & $(-1.78)$ & $(-0.56)$ & $(0.46)$ & $(-1.13)$ \\
\hline \multirow[t]{2}{*}{ ECCAS } & 0.126 & -0.417 & 0.0859 & $-0.643^{*}$ & -0.0415 & 0.489 & -0.598 & 0.122 & -0.333 & -0.329 \\
\hline & $(1.17)$ & $(-0.98)$ & $(0.19)$ & $(-2.02)$ & $(-0.16)$ & $(1.28)$ & $(-1.40)$ & $(0.48)$ & $(-1.08)$ & $(-0.64)$ \\
\hline \multirow[t]{2}{*}{ ECOWAS } & 0.0481 & -0.432 & -0.145 & -0.432 & -0.131 & 0.459 & -0.615 & 0.155 & -0.414 & -0.4 \\
\hline & $(0.84)$ & $(-1.20)$ & $(-0.35)$ & $(-1.51)$ & $(-0.57)$ & (1.28) & $(-1.56)$ & $(0.70)$ & $(-1.37)$ & $(-0.87)$ \\
\hline \multirow[t]{2}{*}{ IGAD } & $-1.371^{* * *}$ & $-3.359^{* * *}$ & $-2.427^{\star * *}$ & -0.371 & $-1.434^{\star \star}$ & $-4.440^{* * *}$ & $-5.578^{\star \star *}$ & $-1.053^{\star * *}$ & $-2.961^{* * *}$ & $-4.512^{\star * *}$ \\
\hline & $(-5.33)$ & $(-5.33)$ & $(-6.27)$ & $(-1.32)$ & $(-3.07)$ & $(-12.58)$ & $(-13.06)$ & $(-4.09)$ & $(-8.15)$ & $(-6.29)$ \\
\hline \multirow[t]{2}{*}{ SADC } & 0.188 & 0.355 & 0.283 & 0.275 & 0.242 & -0.266 & -0.0697 & -0.113 & 0.0835 & 0.485 \\
\hline & $(1.10)$ & $(0.83)$ & $(1.02)$ & $(1.23)$ & $(0.85)$ & $(-0.91)$ & $(-0.19)$ & $(-0.49)$ & $(0.47)$ & $(1.00)$ \\
\hline Country pair FE & Yes & Yes & Yes & Yes & Yes & Yes & Yes & Yes & Yes & Yes \\
\hline Reporter FE & Yes & Yes & Yes & Yes & Yes & Yes & Yes & Yes & Yes & Yes \\
\hline Partner FE & Yes & Yes & Yes & Yes & Yes & Yes & Yes & Yes & Yes & Yes \\
\hline \multirow[t]{2}{*}{ _cons } & $1.255^{* * *}$ & $4.936^{* * *}$ & $2.490^{\star * *}$ & $1.879^{* * *}$ & $1.121^{\star}$ & $4.238^{* * *}$ & $6.020^{* * *}$ & -0.219 & $2.191^{* * *}$ & $5.950^{* * *}$ \\
\hline & $(4.80)$ & $(6.21)$ & $(5.30)$ & $(3.86)$ & $(2.15)$ & $(6.47)$ & $(9.62)$ & $(-0.41)$ & $(4.77)$ & $(6.74)$ \\
\hline$N$ & 13924 & 13924 & 13924 & 13924 & 13924 & 13924 & 13924 & 13924 & 13924 & 13924 \\
\hline
\end{tabular}

$t$ statistics in parentheses. ${ }^{*} p<0.05,{ }^{* *} p<0.01,{ }^{* * *} p<0.001$.

We begin our discussion with the standard gravity variables. Table 4 shows that the estimated GDP coefficients have the expected sign and significance in all the 10 regressions. The parameter estimates of population size also are positive and significant in most cases especially the population size for the reporter countries, i.e., the importer countries. This implies that the higher the population of a country the higher the demand for imported goods all else constant.

Bilateral distance has a large effect on trade of the selected agricultural products. As expected the parameter estimates of the distance variable are negative and statistically significant at the 1 per cent significant level irrespective of the products. Thus, the volume of trade in each of the selected commodities diminishes as distance increases. The coefficients for all commodities are more than 1 .

We used the log of air distance between the capital cities of the respective countries as the proximity measure. Like other studies on gravity, we presume that the direct air distance is a reasonable proxy for transportation cost. How- 
ever, it should be noted that transportation cost will not always increase monotonically with distance because transaction costs associated with many operations such as loading, storage, and local distribution, are large compared to the marginal cost per kilometre of distance travelled [28].

The negative and significant effect of distance on agrifood products is in conformity with similar findings by [19] [20]. The other standard gravity variables such as being landlocked, common language, colonial history and contiguity all have the expected sign and are significant in most cases.

\subsection{Trade Creation}

Empirical results on Table 5 suggest that there is mixed effect of the regional integrations in Africa. Among the eight RTAs considered, IGAD, EAC and COMESA have shown positive and significant trade creation effect in the overall agrifood commodities. IGAD shows positive and significant trade creation effect in seven of the nine selected agricultural products followed by EAC which showed positive and significant effect on three products, and finally COMESA and ECOWAS showed positive and significant effect in one product each.

In the next group of RTAs namely AMU, ECOWAS and SADC the trade creation effect for overall agrifood commodities, although positive, is statistically insignificant. This indicates the fact that the three trade agreements have not resulted in creation of trade in the selected agricultural products.

In the third group of RTAs, CENSAD and ECCAS, trade decreased after the formation of the agreements in seven out of nine, and in three out of nine agrifood commodities respectively. Moreover, trade in all agrifood commodities has decreased following the formation of the agreement in CENSAD and ECCAS over the period 1998-2010.

\subsection{Trade Diversion}

Observing the level of changes in each of the eight RECS, the diversion dummy, can give insight into the presence of trade diversion effects. This will tell us whether there are reductions in the level of imports by each of the RECs member states from non-members relative to the level of exports by the REC members to non-members overtime. The relevant results are reported on Table 6.

The signing of CENSAD and IGAD appear to have come at the expense of trade diversion with non-members. Table 4 indicates that trade diversion is observed in CENSAD and IGAD member states in seven and eight of the nine agrifood commodities respectively. In the case of CENSAD none of the trade diversions are compensated by any trade creation effect. However, in the case of IGAD trade diversion is more than compensated in four of the eight agrifood commodities in which trade diversion occurred. Trade diversion coefficient is positive and significant for one commodity, i.e., beef in the case of COMESA implying that beef imports by COMESA member states from non-member states has increased. For the remaining RTAs, no significant changes have been ob- 
served in trade diversion over the period 1998-2010 as a result of the formation of trade agreements among the member states.

\subsection{Net Effect}

We now turn to look into the net effect of the trade creation and trade diversion effects for each of the eight RECs on the nine selected agrifood commodities. But for simplicity, we limit the net effect analysis to the total agrifood products.

Comparing the trade creation and trade diversion coefficients, the sum of the two coefficients gives the net creation effect of trade agreements. Table 7 indicates that among the eight RTAs considered, CENSAD and ECCAS recorded a net diversion effect, while three RTAs-COMESA, EAC and IGAD show a net creation effect. In the case of AMU, ECOWAS and SADC neither net creation nor net diversion effect was recorded.

In summary, results suggest that the African RTAs have a mixed effect. The net effect for total agrifood commodities is positive and significant in three of the eight trading blocs in Africa and it is negative or insignificant in the remaining five RTAs. In two of these three trading blocs with net trade creation effects-COMESA and EAC, trade among member states has increased significantly while either increasing their openness to the rest of the world or without changing the level of openness to the rest of the world. These trading blocs are good indications that trading blocs in Africa are favourable to both regional integration and formation of a common African market that transcends national and sub-regional borders as envisaged by the African Union. However, a lot remains to be done to have a full benefit of regional integration in all the trading blocs in Africa.

\subsection{Implications to Food Security}

The analysis in previous sections demonstrates that regional integration of the selected agrifood markets in Africa ispartial. For some of the selected agrifood commodities, trade creation effect is positive and significant and for others not. Similarly, trade diversion is negative and significant for some commodities and

Table 7. Net trade creation effect.

\begin{tabular}{cccc}
\hline & Trade Creation & Trade diversion & Net effect \\
\hline AMU & 0.216 & -0.423 & 0 \\
CENSAD & $-3.556^{* *}$ & $-5.723^{* * *}$ & -9.279 \\
COMESA & $1.168^{*}$ & $1.086^{*}$ & 2.254 \\
ECCAS & $-2.549^{* * *}$ & -0.329 & -2.549 \\
ECOWAS & -0.109 & -0.4 & 0 \\
EAC & $2.370^{* *}$ & -0.423 & 2.370 \\
IGAD & $6.746^{* * *}$ & $-4.512^{* * *}$ & 2.234 \\
SADC & 0.611 & 0.485 & 0 \\
\hline
\end{tabular}


for others it is positive and statistically significant implying higher level of openness of the African trading blocs to outside members. Looking at the net effect for the total agrifood commodities, net trade creation has been seen in three trading blocs and net trade diversion in two trading blocs. In three trading blocs, the net trade creation is zero.

What does this mean for regional food security and sustainable agricultural development? This implies that the regional integration has not led to substantial allocation effects and the expected decrease in food prices caused by efficiency gains. Hence, the direct effect of African RTAs on food security, although different among trading blocs, seems to have been small. Although accumulation effects can have a potentially much larger and positive effect on improving food security by stimulating agricultural development and poverty reduction due to its dynamic nature, taking into account that allocation effects have been small, it seems likely accumulation effects have also been limited.

This does not mean that more and better regional integration does not offer important opportunities to improve food security in Africa for two reasons. First, along many borders in Africa, there are large informal flows of food grains that are not subject to tariffs and trade restrictions whose effects could not be accounted in our model. Numerous studies have shown that informal cross border trade especially in traditional food grains such as maize, rice and beans and live animals is substantial [29]. In some instance, the volume of informal cross border trade among many African countries is estimated to be much larger than the official cross border trade [30]. In Uganda, for example, informal exports flowing to its five neighbouring countries were estimated to account for USD 231.7 million in 2006, corresponding to around 86\% of Uganda's official export flows to these countries. Similarly, informal imports were estimated at USD 80.6 million, corresponding to approximately $19 \%$ of official import flows from these countries [31]. When formal trade is increasingly liberalized and strong restrictions are placed on the informal trade overtime, the effects of RTAs in enhancing food security in Africa would undoubtedly rise up. Secondly, the fact that intra-regional agriculture and food trade in Africa is relatively low in comparison with intra-regional agricultural trade in other regions (see Table 2) means that there is sufficient scope for expansion. In the sub-section that follows, we show the potential implication of regional integration in Africa to food security by comparing regional production instability index with individual countries instability index.

\section{Production Variability and Intraregional Trade Potential}

Empirical evidences lead to the conclusion that food consumption in a region will be more stable if its production is more stable than that in individual countries and if trade between countries is allowed [32]. Following [32] [33] [34], food security is analysed here with reference to the instability of year-to-year food production (relative to their trend) which holds implications ultimately for the variability of food prices. 
Instability is measured with the Cuddy Della Valle Instability index [35]. The index is a modification of $\mathrm{CV}$ to accommodate for trend, which is commonly present in time series economic data. It is based on the coefficient of variation corrected by the fitness of a trend function. Thus,

$$
I=\mathrm{CV} \sqrt{1-\bar{R}^{2}}
$$

where $\mathrm{CV}$ is the coefficient of variation and $\bar{R}^{2}$ is the adjusted coefficient of determination of an arithmetic linear or log-linear trend function. Formulated by [35], this index provides a cardinal measure of the instability of time series data relative to their respective trends. The instability of domestic production series indicates the food security circumstances that would prevail in countries under autarky.

Instability indexes (I), which are corrected coefficients of variation, have been calculated for ten of the twelve strategic agricultural products identified by the African Union on the basis of data from 1991-2012 for each of the eight RECs member countries ${ }^{1}$. Table 8 presents the instability index of individual countries and the corresponding regions instability index. Thus one can see the relationship between the regions instability index and those of the individual countries.

One general observation from the individual countries instability index is that production of the strategic agricultural products is highly volatile almost in all African countries whose production data is available. For all countries where production data is available, production fluctuations are more than $10 \%$. Some of the strategic products particularly oil palm and to some extent groundnut are produced in a few of the RECs. Production of oil palm is reported only for ECCAS and ECOWAS.

Table 8 reveals that there are wide differences in individual countries instability index when compared to their region's instability index. For some products, regional instability index exceeds individual country's instability index. ECOWAS is the region with high volatility of production at regional level than at country level. For eight of the ten strategic agricultural products considered, regional instability index is higher than some member states instability index. This means that the countries with lower instability index than the regional index would not gain if integration is enhanced. This indicates that national incentives to cooperate regionally can vary widely. Next to ECOWAS, CENSAD reveals higher regional instability index than individual countries instability index for five strategic agricultural products namely legumes, maize, rice, sorghum and sugar. IGAD comes in third place with regional instability index exceeding some members' instability index in three products. For the remaining RECs, regional instability index exceeds some member states instability index for either two products (in the case of EAC, ECCAS and SADC) or only one product (in the case of AMU).

${ }^{1}$ Data for period 1991-2012 was obtained from FAOSTAT, 2015. For a significantly large number of countries, production data is missing either because the countries do not produce the products or it was not reported. Regional instability indices were constructed using the available data. 
Table 8. Instability of strategic agricultural products production in Africa by REC, 1991-2012.

\begin{tabular}{|c|c|c|c|c|c|c|c|c|c|c|c|}
\hline \multirow{2}{*}{ REC } & \multirow{2}{*}{ Country } & \multicolumn{10}{|c|}{ Strategic Agricultural Products } \\
\hline & & Beef & Dairy & Groundnut & Legumes & Maize & Oil Palm & Poultry & Rice & Sorghum & Sugar \\
\hline \multicolumn{12}{|c|}{ AMU } \\
\hline & Algeria & 19.1 & 22.9 & - & 42.8 & 238.6 & - & 18.4 & 148.4 & - & - \\
\hline & Mauritania & - & - & - & - & 144.6 & - & - & - & - & - \\
\hline & Morocco & 20.2 & 17.4 & - & 32.6 & 50.4 & - & 22.7 & 56.6 & - & 14.3 \\
\hline & Tunisia & - & 11.4 & - & 44.3 & - & - & 16.8 & - & - & 73.3 \\
\hline & AMU & 9.7 & 10.2 & - & 25.3 & 49.9 & - & 12.6 & 55.6 & - & 15 \\
\hline \multicolumn{12}{|c|}{ CENSAD } \\
\hline & Benin & - & - & - & - & - & - & - & 177.8 & 168 & - \\
\hline & Burkina Faso & - & - & 42.2 & 36.5 & 31.2 & - & - & 73.4 & 31.8 & - \\
\hline & Chad & 108.2 & - & - & - & - & - & - & 121.4 & 119.8 & - \\
\hline & Comoros & - & - & - & - & - & - & - & - & - & - \\
\hline & Cote D'voire & 21 & 23.5 & 23.1 & 41.7 & 13.7 & - & 26.6 & 60.6 & 102.9 & 19.4 \\
\hline & Egypt & 26.4 & 21.7 & 36 & 20.6 & 12.2 & - & 27.1 & 20 & 17.5 & 32.9 \\
\hline & Eritrea & - & 29 & 76.4 & 66.6 & 55.4 & - & 41.4 & - & 77.9 & - \\
\hline & Ghana & 49.4 & - & 35.5 & - & 16.9 & - & 43.8 & 25.1 & 31.9 & - \\
\hline & Guinea & 19.4 & 20.4 & 32 & - & 19.9 & - & 33.9 & 45.4 & 33.4 & - \\
\hline & Guinea-Bissau & 109.2 & 119.6 & - & - & 85 & - & 108.4 & 43.1 & 36.8 & - \\
\hline & Gambia & 19.1 & - & 24.3 & - & 35.1 & - & 23.4 & 65.9 & 39 & - \\
\hline & Kenya & 22.4 & 28.8 & 41.6 & 34.7 & 16.5 & - & 24.1 & 82.4 & 44.2 & 22.2 \\
\hline & Mali & 39.8 & 51.6 & 47.7 & 37.6 & 53.5 & - & 39.2 & 51.4 & 53.6 & - \\
\hline & Morocco & 20.2 & 17.4 & 16.9 & 32.6 & 51.6 & - & 22.7 & 56.6 & 37.7 & 14.3 \\
\hline & Niger & - & - & 76.5 & 59.3 & 68.6 & - & - & 48.8 & 66.6 & 15.4 \\
\hline & Nigeria & 45.1 & 36.1 & 36.8 & 57.8 & 47.3 & - & 40.8 & 51.6 & 52.1 & - \\
\hline & Senegal & - & 29.7 & 41.8 & 61 & 55.1 & - & 57.8 & 61.3 & 50.1 & 20.4 \\
\hline & Sudan & - & 34.5 & 57.9 & 33.4 & 77.4 & - & 45.4 & 58 & 85.9 & 71.2 \\
\hline & Tunisia & - & 11.4 & - & 44.3 & - & - & - & - & - & 73.3 \\
\hline & Togo & - & - & 32 & 60.6 & 20.8 & - & 16.8 & 41 & 36.6 & - \\
\hline & CENSAD & 13.7 & 7.3 & 14.9 & 34.8 & 24.4 & - & 13.3 & 23.2 & 32.3 & 19.1 \\
\hline \multicolumn{12}{|c|}{ COMESA } \\
\hline & Burundi & 28.6 & 45 & - & 27.1 & 28 & - & 43.5 & 40.4 & 33 & - \\
\hline & Comoros & - & - & - & - & - & - & - & - & - & - \\
\hline & Egypt & 26.4 & 21.7 & 36 & 20.6 & 24.6 & - & 27.1 & 20 & 17.5 & 32.9 \\
\hline & Eritrea & - & 29 & 76.4 & 66.6 & 74.2 & - & 41.4 & - & 77.9 & - \\
\hline & Ethiopia & - & 42.6 & 103.1 & 57.3 & 44.1 & - & - & 115.8 & 50.5 & 28.8 \\
\hline & Kenya & 22.4 & 28.8 & 41.6 & 34.7 & 28.6 & - & 24.1 & 82.4 & 44.2 & 22.2 \\
\hline
\end{tabular}




\begin{tabular}{|c|c|c|c|c|c|c|c|c|c|c|}
\hline Madagascar & 37.3 & - & 30.8 & 23.1 & 40.8 & - & 24.7 & 31.7 & - & 97.5 \\
\hline Malawi & 44.4 & - & 38.6 & 45.1 & 54.6 & - & - & 49.7 & 48.4 & - \\
\hline Mauritius & - & 48 & 93.5 & 34 & - & - & - & - & - & 85.6 \\
\hline Rwanda & 44.4 & 27.3 & 40.3 & 42 & 97.3 & - & 46.3 & 51.9 & 27.4 & 56.9 \\
\hline Sudan & - & 34.5 & 57.9 & 33.4 & 81.5 & - & 57.8 & 58 & 85.9 & 71.2 \\
\hline Zambia & - & - & - & - & - & - & - & - & 104.1 & - \\
\hline Zimbabwe & - & - & - & - & - & - & - & - & 230.2 & - \\
\hline COMESA & 19.9 & 9.5 & 30.7 & 14.7 & 14 & - & 20.2 & 13.6 & 43.9 & 33.3 \\
\hline \multicolumn{11}{|c|}{ EAC } \\
\hline Burundi & 28.6 & 45 & - & 27.1 & 28 & - & 43.5 & 40.4 & 33 & - \\
\hline Kenya & 22.4 & 28.8 & 41.6 & 34.7 & 28.6 & - & 24.1 & 82.4 & 44.2 & 22.2 \\
\hline Rwanda & 25.8 & 27.3 & 40.3 & 42 & 41.9 & - & 46.3 & 51.9 & 27.4 & 56.9 \\
\hline Tanzania & - & 24.8 & 37.7 & 49 & 40.5 & - & - & - & 43.1 & - \\
\hline EAC & 19.9 & 25.2 & 30.7 & 21.2 & 21.5 & - & 18.8 & 27.1 & 32.4 & 21.7 \\
\hline \multicolumn{11}{|c|}{ ECCAS } \\
\hline Angola & - & - & - & - & - & - & - & 222.9 & 252.8 & - \\
\hline Burundi & 28.6 & 45 & - & 27.1 & 28 & - & 43.5 & 40.4 & 33 & - \\
\hline Cameroon & - & 39 & 39.8 & 23.1 & 35.6 & 40.8 & 39.8 & 47.7 & 31.9 & - \\
\hline Congo & 52 & - & 29.1 & 29.9 & 28.9 & 40.1 & 28.5 & 212.1 & - & 32.8 \\
\hline Rwanda & 34 & 27.3 & 40.3 & 42 & 97.3 & - & 46.3 & 51.9 & 27.4 & 56.9 \\
\hline Chad & 108.2 & - & - & - & - & - & - & 121.4 & 119.8 & - \\
\hline ECCAS & 49.2 & 13.4 & 22.4 & 15.1 & 24.8 & 37.7 & 27.5 & 36.7 & 31.5 & 31.9 \\
\hline \multicolumn{11}{|c|}{ ECOWAS } \\
\hline Benin & - & - & - & - & - & - & - & 177.8 & 168 & - \\
\hline Burkina Faso & - & - & 42.2 & 36.5 & 54.6 & - & - & 73.4 & 31.8 & - \\
\hline Cote D’voire & 21 & 23.5 & 23.1 & 41.7 & 19.4 & 44.1 & 26.6 & 60.6 & 102.9 & 19.4 \\
\hline Cape Verde & 26.6 & 42.5 & - & 212.8 & 69.5 & - & 40.1 & - & - & - \\
\hline Ghana & 49.4 & - & 35.5 & - & 31.9 & 18.4 & 43.8 & 25.1 & 31.9 & - \\
\hline Gambia & 19.1 & - & 24.3 & - & 47.5 & 21 & 23.4 & 65.9 & 39 & - \\
\hline Guinea & 19.7 & 20.4 & 32 & - & 22.7 & 24.9 & 33.9 & 45.4 & 33.4 & - \\
\hline Guinea-Bissau & 109.2 & - & - & - & 88.2 & 109.5 & 108.4 & 43.1 & 36.8 & - \\
\hline Madagascar & - & - & 30.8 & - & - & 0 & 0 & 0 & 0 & 0 \\
\hline Mali & 39.8 & 51.6 & 47.7 & 37.6 & 78.2 & - & 39.2 & 51.4 & 53.6 & - \\
\hline Niger & - & - & 76.5 & - & 95.2 & - & - & 48.8 & 66.6 & 15.4 \\
\hline Nigeria & 45.1 & 36.1 & 36.8 & 57.8 & 52.3 & - & 40.8 & 51.6 & 52.1 & - \\
\hline Senegal & - & 29.7 & 41.8 & 60.1 & 68.1 & - & - & 61.3 & 50.1 & 20.4 \\
\hline Togo & - & - & 32 & 60.6 & 35.9 & - & 45.4 & 41 & 36.6 & - \\
\hline ECOWAS & 28.8 & 23.5 & 19.9 & 51.4 & 37.3 & 29.2 & 26.1 & 32.9 & 40.3 & 11 \\
\hline
\end{tabular}




\begin{tabular}{|c|c|c|c|c|c|c|c|c|c|c|}
\hline \multicolumn{11}{|c|}{ IGAD } \\
\hline Eritrea & - & 29 & 76.4 & 66.6 & 74.2 & - & 41.4 & - & 77.9 & - \\
\hline Ethiopia & - & 42.6 & 103.1 & 57.3 & 44.1 & - & - & 115.8 & 50.5 & 28.8 \\
\hline Kenya & - & 28.8 & 41.6 & 34.7 & 28.6 & - & 24.1 & 82.4 & 44.2 & 22.2 \\
\hline Sudan & - & 34.5 & 57.9 & 33.4 & 81.5 & - & 57.8 & 58 & 85.9 & 71.2 \\
\hline IGAD & - & 12.8 & 51.5 & 27.2 & 24.3 & - & 49.5 & 43.1 & 53.8 & 26.5 \\
\hline \multicolumn{11}{|c|}{ SADC } \\
\hline Angola & - & - & - & - & - & - & - & 222.9 & 252.8 & - \\
\hline Botswana & - & 41.3 & - & - & 98.7 & - & - & - & 74.5 & - \\
\hline Congo & 52 & - & - & - & - & - & - & - & - & - \\
\hline Lesotho & - & - & - & - & - & - & - & - & - & - \\
\hline Madagascar & 37.3 & - & - & 23.1 & 40.8 & - & 24.7 & 31.7 & - & 97.5 \\
\hline Malawi & 41.4 & - & 38.6 & 45.1 & 54.6 & - & - & 49.7 & 48.4 & - \\
\hline Mauritius & - & 48 & 93.5 & 34 & - & - & - & - & - & 85.6 \\
\hline Mozambique & 42 & 19.4 & 33.4 & - & 58 & - & 32.6 & 72.9 & 60.4 & 47.5 \\
\hline Namibia & - & 39.6 & - & - & 62.1 & - & 41.3 & - & 59.6 & - \\
\hline South Africa & 35.6 & 22.3 & 34.8 & 18.1 & 30 & - & 27.9 & - & 37.5 & 17.6 \\
\hline Tanzania & - & 24.8 & 37.7 & 49 & 40.5 & - & - & - & 43.1 & - \\
\hline Zambia & - & - & - & - & - & - & - & - & 104.1 & - \\
\hline Zimbabwe & - & - & - & - & - & - & - & - & 230.2 & - \\
\hline SADC & 26.5 & 18.5 & 15.9 & 19.8 & 15.9 & - & 23.8 & 27.5 & 30.1 & 45.3 \\
\hline
\end{tabular}

To sum up, instability index at regional level is much lower than individual countries instability index for most strategic agricultural products in many of the RECs. This implies the fact that regional integration in Africa can enhance stability of production of the strategic agricultural products significantly which in turn can improve food availability and hence food security.

\section{Conclusions}

Agriculture continues to dominate the economies of most African countries and is an important vehicle for economic growth. The sector continues to produce the bulk of food consumed in Africa, employs a significant proportion of the labour force and accounts for significant proportion of exports and GDP in many countries. Despite the importance of agriculture in their economies, trade in agricultural products amongst the African countries remains at a relatively low level. It is increasingly being recognized that African food and agricultural markets are extremely fragmented along sub-region, national and even sub-national levels, resulting in segmented markets of sub-optimal size which hinder the profitability of sizeable private investment in the different stages of the com- 
modity chain.

The problems of food security and sustainable agricultural development have been at the forefront of the debate on Africa's development since the Lagos plan of Action in 1963 and the Abuja Treaty of 1991. In the December 2006 AU/ NEPAD summit on Food Security in Africa, a practical solution to this problem evolved. Few strategic commodities, that represent important weight in African food basket, weigh significantly in the trade balance in the region and have considerable unexploited production potential, were identified and decided to move market integration beyond the current pace of reform to create a free trade zone at the continent level.

The objective of this research is to evaluate the trade creation effects on the selected agricultural products. It addressed the fundamental question of what effect RTAs in Africa have had on trade in the selected agricultural products, and what is the implication of this on food security. To answer this question, we developed an extended gravity model to estimate the magnitude of trade creation and trade diversion across 9 individual agrifood commodities and for 8 RTAs.

Although the welfare effects are ambiguous when trade creation and trade diversion effects occur, comparison of trade creation and trade diversion for total agricultural commodities reveal that in three of the eight African RTAs, trade creation far outweighs trade diversion leading to net trade creation effects and hence welfare gain. But in two RTAs, trade diversion exceeds trade creation leading to a net trade diversion and hence welfare loss. For the remaining three RTAs, trade creation is similar to trade diversion and hence difficult to tell the welfare effect.

Are regional trade agreements in Africa building blocks or stumbling blocks in the market integration of agricultural products in Africa? What is the implication of this on food security and sustainable agricultural development?

Our extended gravity model results suggest that some of Africa's regional trade agreements are effective avenues to promote common market for agricultural products. Furthermore, for a few individual agrifood commodities, regional trade agreements in Africa have increased openness to non-members' trade while increasing trade among themselves to some extent. Thus, RTAs in Africa are an attractive means to speed up the move towards common market for agricultural products in the continent. This will have positive implications for food security and sustainable agricultural development on the continent. Furthermore, production instability index is smaller at regional level than at individual country level despite some exceptions. This indicates the potential to stabilize production of the strategic agricultural commodities which in turn can enhance food security if integration process in Africa RTAs is enhanced.

\section{Conflicts of Interest}

The authors declare no conflicts of interest regarding the publication of this paper. 


\section{References}

[1] FAO (2014) The State of Food Insecurity in the World 2014. Strengthening the Enabling Environment for Food Security and Nutrition. Food and Agriculture Organization of the United Nations, Rome.

[2] FAO (2008) Towards an African Common Market for Agricultural Products. Food and Agriculture Organisation of the United Nations, Rome.

[3] UNCTAD (2009) Economic Development in Africa Report 2009: Strengthening Regional Economic Integration for Africa Development, New York and Geneva.

[4] World Bank (2000) Trade Blocks, Policy Research Report. Oxford University Press, Ney York.

[5] Yeats, A. (1998) What Can Be Expected from African Regional Trade Arrangements? Some Empirical Evidence, World Bank, Mimeo.

[6] Schiff, M. (1997) Small Is Beautiful: Preferential Trade Agreements and the Impact of Country Size, Market Share, and Smuggling. Journal of Economic Integration, 12, 359-387. https://doi.org/10.11130/jei.1997.12.3.359

[7] Park, J.H. (1995) The New Regionalism and Third World Development. Journal of Developing Societies, 11, 21-35.

[8] Elbadawi, I. (1997) The Impact of Regional Trade and Monetary Schemes on Intra Sub-Saharan Africa trade. In: Ademola O., Elbadawi, I. and Collier, P., Eds., Regional Integration and Trade Liberalization in Sub-Saharan Africa, Macmillan, Houndmills, Basinstoke, London.

[9] Evans, D. (1998) Options for Regional Integration in Southern Africa. IDS Working Paper 94, Institute of Development Studies, Sussex.

[10] Lewis, J.D., Robinson, S. and Thierfelder, K. (1999) After the Negotiations: Assessing the Impact of Free Trade Agreements in Southern Africa. TMD Discussion Paper, International Food Policy Research Institute, Washington DC.

[11] Flores Jr., R. (1997) The Gains from MERCOSUL: A General Equilibrium, Imperfect Competition Evaluation. Journal of Policy Modeling, 19, 1-18. https://doi.org/10.1016/0161-8938(95)00139-5

[12] Cernet, L. (2001) Assessing Regional Trade Arrangements: Are South South RTAs More Trade Diverting? Policy Issues in International Trade and Commodities Study Series No. 16, United Nations, New York.

[13] Baier, S.L. and Bergstrand, J.H. (2007) Do Free Trade Agreements Actually Increase Members' International Trade? Journal of International Economics, 71, 72-95. https://doi.org/10.1016/j.jinteco.2006.02.005

[14] Baier, S.L., Bergstrand, J.H. and Feng, M. (2014) Economic Integration Agreements and the Margins of International Trade. Journal of International Economics, 93, 339-350. https://doi.org/10.1016/j.jinteco.2014.03.005

[15] Anderson, J.E. (2011) The Gravity Model. Annual Review of Economics, 3, 133-160. https://doi.org/10.1146/annurev-economics-111809-125114

[16] Dijk, M.V. (2011) African Regional Integration: Implications for Food Security. http://ssrn.com/abstract $=1788157$

[17] Cervantes-Godoy, D. and Dewbre, J. (2010) Economic Importance of Agriculture for Poverty Reduction. OECD Food, Agriculture and Fisheries Working Paper No. 23.

[18] FAO (2003) Trade Reforms and Food Security: Conceptualizing the Linkage. Food and Agriculture Organisation of the United Nations, Rome. 
[19] Jayasinghe, S. and Sarker, R. (2007) Effects of Regional Trade Agreements on Trade in Agrifood Products: Evidence from Gravity Modelling Using Disaggregated Data. Review of Agricultural Economics, 30, 61-81. https://doi.org/10.1111/j.1467-9353.2007.00392.x

[20] Grant, J.H. and Lambert, D.M. (2005) Regionalism in World Agricultural Trade: Lessons from Gravity Model Estimation. The American Agricultural Economics Association Annual Meeting, Providence, 24-27 July 2005.

[21] Márquez-Ramos, L. and Martinez-Gomez, V. (2015) Revisiting the Effect of Trade Preferences Granted to Morocco in the Light of an Export-Orientated Approach for Food Security. In: Paciello, M.C., Ed., Building Sustainable Agriculture for Food Security in the Euro-Mediterranean Area: Challenges and Policy Options, Istituto Affari Internazinali (IAI), Edizioni Nuova Cultura, Roma, 207-224.

[22] Dhehibi, B., Frija, A., Telleria, R. and Aw-Hassan, A. (2015) The Effect of Trade Liberalization on the Sustainability of Agricultural Sectors in Egypt and Tunisia: A New Framework Based TFP Growth Structure. In: Paciello, M.C., Ed., Building Sustainable Agriculture for Food Security in the Euro-Mediterranean Area: Challenges and Policy Options, Istituto Affari Internazinali (IAI), Edizioni Nuova Cultura, Roma, 179-201.

[23] UNCTAD (2013) UNCTADstat. http://unctad.org/en/pages/Statistics.aspx

[24] Frankel, J., Stein, E. and Wei, S.J. (1995) Trading Blocs and the Americas: The Natural, the Unnatural, and the Super Natural. Journal of Development Economics, 47, 61-95. https://doi.org/10.1016/0304-3878(95)00005-4

[25] Frankel, J. and Wei, S.J. (1998) Regionalization of World Trade and Currencies: Economics and Politics. In: Frankel, J., Ed., The Regionalization of the World Economy, National Bureau of Economic Research, University of Chicago Press, Chicago.

[26] Wooldridge, J.M. (2002) Econometric Analysis of Cross-Section and Panel Data. MIT Press, Cambridge.

[27] Mayer, T. and Zignago, S. (2011) Notes on CEPII's Distances Measures: The GeoDist Database. CEPII Working Paper.

[28] Frankel, J. (1997) Regional Trading Blocs in the World Economic System. Institute for International Economics, Washington DC.

[29] Afrika, J.G. and Ajumbo, G. (2012) Informal Cross-Border Trade in Africa: Implications and Policy Recommendations. Africa Economic Brief, 3, 1-15.

[30] Golub, S. (2015) Informal Cross-Border Trade and Smuggling in Africa. In: Morrissey, O., López, R.A. and Aharma, K., Eds., Handbook on Trade and Development, Edward Elgar Publishing, Cheltenham, UK Northampton, 179-209.

https://doi.org/10.4337/9781781005316.00016

[31] Lesser, C. and Moisé-Leeman, E. (2009) Informal Cross-Border Trade and Trade Facilitation Reform in Sub-Saharan Africa. OECD Trade Policy Working Paper No. 86.

[32] Koester, U. (1986) Regional Cooperation to Improve Food Security in Southern and Eastern African Countries. Research Report 53, International Food Policy Research Institute, Washington DC.

[33] Badiane, O. (1991) Regional Agricultural Markets and Development Strategies in West Africa. Quarterly Journal of International Agriculture, 30, 37-50.

[34] De Rosa, D.A. (1995) International Trade, Food Security and Regional Integration in the Middle East. TMD Discussion Paper No. 3, International Food Policy Re- 
search Institute, Washington DC.

[35] Cuddy, J.D.A. and Della Valle, P.A. (1978) Measuring the Instability of Time Series Data. Oxford Bulletin of Economics and Statistics, 40, 79-85.

https://doi.org/10.1111/j.1468-0084.1978.mp40001006.x 